\title{
THE BOUNDARY OF UKRAINIAN RENAISSANCE LITERATURE
}

\author{
Olha Lisovska \\ Postgraduate Student, Taras Shevchenko National University of Kyiv, Ukraine \\ e-mail: shchelkunova2017@ukr.net,orcid.org/0000-0002-0030-3592
}

\section{Summary}

The aim of this paper is to investigate the influence of European culture on the formation of Ukrainian literature of the 14th-16th centuries. It is emphasized that the paradigm of Ukrainian Renaissance literature is a synthesis of original native ideas and Western European culture. The specific of Ukrainian boundary is represented in the absence of Ukrainian state, confessional pluralism, multilingualism, syncretic character, the popularity of humanism, and anthropocentrism. The identification boundary identity as a key feature of the Ukrainian Renaissance literature is also based on geopolitical location of the country.

Methods used in the study: general scientific method (synthesis and generalization), systematic functional, textual method, and systematic descriptive. The comparative-typological and philological methods are used for the analysis of works where the border identity is represented. It is also applied the principles of socio-cultural and historical-typological analysis. The determining factor in the work is the historical and literary approach, which is based on the synthesis of cultural theories and literary analysis.

Keywords: culture, Europe, humanism, anthropocentrism.

\section{DOI: https://doi.org/10.23856/4906}

\section{Introduction}

The Renaissance era in the history of European civilization, in particular literature, became transitional from Middle Ages to the Baroque. The Renaissance had its origin in Italy, from where innovative cultural-literary and spiritual-confessional traditions spread to Western and Central Europe, Czech Republic, Poland, Hungary, Transylvania, Dalmatia, and Northern Croatia. The first manifestations of proto-Renaissance ideas appeared in the second half of the $13^{\text {th }}$ century in Italy. Then they spread to other states, staying dominated till the last quarter of the $16^{\text {th }}$ - the beginning of the $17^{\text {th }}$ centuries. At that time Ukraine was the part of the Grand Duchy of Lithuania, therefore, scientists did not consider Ukrainian Renaissance as an original phenomenon for a long time. For this reason, the detailed analysis of the problem of independence and self-sufficiency of the Ukrainian literature is relevant. In the latest studies of Ukrainian historical and literary science, it is concluded that the Ukrainian Renaissance literature dates mainly to the $16^{\text {th }}$ century, and it is developed in the context of European artistic trends, synthesizing the national heritage.

\section{Political influence on Ukrainian culture}

Ukrainian immigrants educated in Italy, Germany, France, Poland, and Czech Republic adopted main Renaissance tendencies to the Rus-Ukrainian literature. Staying a part of Lithuania and Poland determined the influence of these cultures, in particular the Polish one, which made it impossible for an integral-complex reproduction of the leading Renaissance 
tendencies. However, traditionally formed cultural-literary and spiritual-confessional model of the Renaissance was not totally imposed and applied to Ukrainian literature. It became the topic for scientific discussions.

The unifying category of thought for the Renaissance was humanism. A. Losev notes, "The Renaissance was not in one country, but in all countries (we are talking about Europe O.L.), and each experienced its own Renaissance in its own chronology and with its own sense" (Losev, 1978: 51). According to I. Golenishchev-Kutuzov, "from the shores of the Adriatic to the Baltic, from Prague to Vilna in the 15 th -17 th centuries, there was a process of assimilation of humanistic ideas, not as significant as in Western Europe" (Golenishchev-Kutuzov, 1963, p. 258). All European Renaissance literature, realistic tendencies were widespread, which were transformed into Renaissance realism and Renaissance classicism. The Latin language played the role of the language of the supranational "republic of scientists". Education was based on the humanistic model as the defining one for Western European educational institutions. The Renaissance presented itself primarily in the form of humanism, which proclaimed attention to the individual, the reorientation from theocentrism to anthropocentrism, the happiness and self-realization of a person as the main ones in his life, the awareness of man as a defining value, the development of sciences regardless of religion. Pico de Mirandola wrote that God is the beginning, and man is the center of all things. It was a transition from studium divinum to studium humanum. In fact, a new worldview was formed, in the context of which, as noted by A. Losev, humanism was seen as "philosophical-mitological, poetic and personally-enthusiastic consciousness" (Losev, 1978: 109).

\section{Interference of literatures}

A distinctive feature of the European literary process was the interference between national literatures, which gave rise to extreme or borderline identities. In fact, both Western and Central Europe, including Poland, had cultural and spiritual interference. The incorporation of the Ukrainian lands into Lithuania and Poland made them accessible to pan-European influences and created new artistic trends in the literature. The Kyivan Rus tradition was renewed and enriched with new Western trends. That was one way how Ukrainian Renaissance was formed.

After the Union of Lithuania with Poland on the territory of Ukraine, two cultures were mixed - "Polish, based on the Western foundations of the feudal system, and Russian, converted from Byzantine sources" (Efremov, 1995: 113). The Polish influence becomes decisive.

A significant feature of cultural development is the development of printing houses, brotherhoods and fraternal schools, which become "hotbeds of a new cultural life and national educational movement in Ukraine" (Efremov, 1995: 114). The first printed books were supplied to Rus from the Krakow printing house, where, thanks to the support of Prince Konstantin Ostrozhsky, "The Octopus," "Hours", "Psalter", "Triodes" were published. In Prague, he began publishing books by Francysk Skaryna, who published the "Bible", "Psalter", "Apostle". Ivan Fedorovich (Fedorov) and Pyotr Mstislavich founded a printing house in Zabludovo, where the Teaching Gospel and the Psalter were published. Later, in Ostrog, Fedorovich published the Ostrog Bible (1581). S. Efremov notes that the publication of the Ostroh Bible "constitutes a turning point in the history of Ukrainian writing of that time. Starting from that date, our literature goes beyond the framework of chance and acquires the character of planned and systematic work, fanned by a certain idea - promotion, liberation and struggle for national interests under the firm of religious interests" (Efremov, 1995: 120). Ukrainian philistines created brotherhoods, that originated from old church "brotherhoods, only reformed, like the newest guild societies, and began to take care 
not only of church affairs and related to church philanthropic, but also of educational and cultural; from churches and hospitals, they also moved to schools and printing houses and for a while became real deputies and defenders of their native nation " (Efremov, 1995: 117). The largest were the Lviv, Vilenske, Beresteyske, Lutske, Kiev brotherhoods, which set as their goal the protection of their native people. The oldest translation of the Holy Scriptures into Ukrainian belongs to the Renaissance era - "Peresopnytsia Gospel" (1556 - 1561).

It was important that Ukrainian leaders, while studying in Europe, studied Latin and write in it. The Renaissance era provided Ukrainians with the opportunity to choose the language of communication and creativity. The fulfillment of the literary function in Latin and the formation of humanism as a new ideological feature increased interest in antiquity. V. Shevchuk emphasized, "As V. Shevchuk writes, "the ancient ideal of beauty as harmonious, and therefore clearly comprehended and organized, has been returned; attention was paid to the value and high value of the human personality, its liberation from medieval dogmas; the world was not considered as a haven for evil (the devil) as it was according to Christian orthodoxy, which demanded the world to curse and leave, but as a receptacle of beauty, because of which man began to be seen as a component of nature, as a creation of a higher reason and a rational being " (Shevchuk, 2004: 80). It was antiquity, which stimulated the secularization of literature, the development and gradual dominance of secular themes in it. The literary texts were based on the ancient ideals of beauty, the concept of individualism, the idea of patriotism, and an appeal to national history were affirmed.

According to V. Shevchuk, in Ukraine the Renaissance developed as an aesthetic trend, not covering all types of art. This was due to the fact, that for a long time Rus-Ukraine was under the influence of the Byzantine cultural space, its literature was created by representatives of the Orthodox confession. However, the first representatives of Renaissance ideas in the Ukrainian territories were the representatives of the "Catholic movement" (the term had its origin in the $16^{\text {th }}$ - the first half of the $17^{\text {th }}$ century). These were young Ukrainian people, who, while studying in Western Europe, changed the Orthodox faith to the Catholic. They added Rusin, Rutenets, Roksolyanin to their names. "Their poetry and prose are permeated with the poetics of the Renaissance, built on ancient models and ideas of humanism. The reaction to the literary renaissance in Ukraine was the polemical work of I. Vishensky, which formally and ideologically signified the transition to the Baroque - this determined the combination of Byzantism with the Renaissance and, to a certain extent, the assimilation of the ideas of reformism (Shevchuk, 2004: 81). Examples of purely Renaissance poetics, for example, the poem by Ivan Dombrovsky "Dnieper stones", the Ukrainian-Polish poetry of Simon Simonid, the Zimorovich brothers, Yan Shchasny-Herbut, Martin Pashkovsky and others. They often called themselves humanists (from Latin "humanitas" - human). In the history of literature, the following characteristic of the properties of humanists has been established: the perception of a person as an integral and complex organism, consisting of two equal principles - flesh and spirituality; the affirmation of the human right to happiness already on earth, and not only in paradise; striving to idealize the image; focus on samples of ancient literature and art; understanding of life's blessings and passions as a necessary part of human life; spreading love not only to religious values, but also to a person; respect for a person according to his qualitative assessment. In addition to the revival of antiquity as one of the defining features of the Renaissance, he "also brought a new discovery of man and nature. Cultural figures, in particular literature, Yuri Drohobych, Stanislav Orikhovsky, Pavel Rusin, and Sebastian Klenovich with their creativity they reacted to foreign policy circumstances, first of all, the domination of Polish influences on a Ukrainian basis. This was manifested in the increased 
attention to Ukrainian life, its originality (Sebastian Klenovich "Roksolania"). The theme of the struggle of a person for personal happiness became the leading theme (historical and memoir prose by Stanislav Orikhovskiy). In general, Ukrainian Renaissance literature is imbued with a deep interest in personality, spiritual protest, glorification of human beauty, connection with life. The writers focused on the illumination of human nature and its inner world. In an effort to respond to topical issues of human existence, they simultaneously turned to national history and the legendary past. Stanislav Orikhovskiy makes the issue of national freedom central in his work, and Sebastian Klenovich glorifies his native land.

It should be noted that the specific of the Ukrainian Renaissance is in the fact that it already existed at the equator of its development in parallel with the reformist currents and tendencies. The Reformation almost completely supplanted the Renaissance in Ukrainian literature and evenly transformed into the cultural and historical Baroque. V. Shevchuk noted, "Renaissance humanism and reformism had the character of elitist phenomena in our land, that is, they were cultivated in the highest spheres of society, essentially cut off from the masses, therefore they did not launch deep roots into the popular consciousness, but, on the other hand, were of great importance for the development of Ukrainian culture. If we talk about literature, then, being a sporadic phenomenon in the first half of the 16th century, the Ukrainian poetic Renaissance was created within the limits of Polish culture by immigrants from Ukraine, who, however, did not cease to recognize themselves as Ukrainians. In general, these people felt, figuratively speaking, the servants of the common European Parnassus and wrote their works on common topics, sometimes without a deeper connection with life in their native land" (Shevchuk, 2004: 79). In the end of the $16^{\text {th }}$ century, there is an upsurge of polemical literature, that is, the reformation movements that marked the beginning of Baroque literature.

The Italian researcher Giovanna Broji Berkoff noted that the main feature of the Ukrainian culture of the 16 th -17 th centuries was its "polymorphism" -multilingualism, multiconfessionalism, multicontextuality and a certain compliance to assimilation influences coming from outside (Brogi Bercoff,2003). The scientist believes that this elasticity of the so-called "cultural code" is explained by the immanence, the tendency to synthesize different traditions, which was inherent in the culture of the Kiev Russian times. At the same time, it also plays a functional role, a response to the threat of disintegration of the cultural community, which has not yet fully formed (Brogi Bercoff, 2003: 325-387). This is exactly the kind of Ukrainian identity that was not fully formed during the Renaissance. Accordingly, this affected its culture and literature.

An important aspect of understanding the essence of borderline identity is the use of certain names and terms to designate the Fatherland during the Renaissance. N. Yakovenko states, "by the middle of the 16th century, Rus, Rus land and the concept of Rusyns (no longer as a political name, but as an ethnonym) both in the Kingdom of Poland and in the Grand Duchy of Lithuania do not know any competition, habitually outlining the ancient Russian territory and its population" (Yakovenko, 2012: 11-12). The terminology of the Pontifical Chancellery was of great importance for the perception of Rus-Ukraine in Europe, in particular that part of it, that was called Western. In the documents of the head of the Roman Church, "a specific conceptual dualism was consolidated: the country itself was called Russia, and its Rusyns were called Rutheni. The words Ruthenus and Rusyn are exclaimed phonetically, and this ideally corresponded to the orientation of medieval geography towards the ancient tradition, from which names of countries and peoples similar in sounding were chosen and applied to new realities" (Yakovenko, 2012:12) There were two names for Rus-Ukraine at that time - Ruthenia and Roxolania. According to N. Yakovenko, that "was a product not so linguistic as sociocultural - a side effect of the triumphant establishment 
of gentry liberties in the Kingdom of Poland during the $16^{\text {th }}$ century. This prompted the emergence of a supra-ethnic and super-confessional ideology of the "gentry people". One of its strong points was the conviction that the gentry and people were separated by an insurmountable abyss of "different blood" (Yakovenko, 2012: 14). The basis of such a worldview was the spread of the so-called Sarmatian ideology and the Sarmatian-ethnogenetic legend, the essence of which was that the biblical genealogy of the gentry was derived from Noah's son Japheth, and the common people from Noah's son Ham. The Sarmatians were considered the descendants of Yafet, who settled on the lands of Russia and Poland. So, the Sarmatians were interpreted as a people, as departed from the Poles and Russians. Shlyakhtich-Rusyns "identified themselves with the" Sarmatian tribe of Roksolans ", brothers of the" Polish Sarmatians ", therefore, the legitimate heirs of the" Sarmatian heritage "(Yakovenko, 2012: 14).

The Renaissance thinker and writer Stanislav Orekhovsky identified his fellow countrymen from Russia with the Sarmatians-Roksolans. He called himself Ruthenus and Roxolanus. He called Russia Roksolania. As N. Yakovenko notes, "the name choice dilemma, in fact, was a dilemma of two versions of" Russianness ". It is clear that both versions were completely loyal to the political fatherland - the Commonwealth, but, somewhat simplifying, the "Roksolan" version can be identified with a tolerant attitude towards everything Polish, and its circumvention - with disdain for "Poland" (Yakovenko, 2012: 18). Accordingly, on the border of two peoples and cultures - Ukrainian and Polishtwo types of writers are formed, which differ precisely by their ideological principle. In general, in the $16^{\text {th }}$ century, the term "roxolans" was mainly used by representatives of the Catholic movement, RusynsCatholics, as well as Polish who were their supporters. The name "Roksolania" is identified with the lands that belonged to the composition of Russia, starting from the time of Vladimir the Great, that is, in fact, at the time of the baptism of the state. Consequently, the lands of the Lithuanian and Belarusian lands were seen separately and were determined by the name Lithuania or White Russia. For example, the Ukrainian-Polish writer Sebastian Klenovich in his poem "Roksolania" (1584) defines the borders of Rus, that is, Roksolania, as the lands of the Kiev region, Podillia, Galicia, Volyn. He represents the commitment to Poland and Russia at the same time, being a representative of the Catholic movement. In parallel "with the spread of the" Roksolan "version of Russian identity, a counter-proposal is gaining momentum - with an expressive" anti-Latin "(and anti-Polish) overtones. Its manifesto is the emphasis on the "Greek" origins of Russia " (Yakovenko, 2012: 19).

The polyformism of the Russian cultural space of the 16th century was the main feature in the structure of the boundary identity of the Ukrainian literature of the Renaissance. It was represented in a synthesis of authentic Russian-Ukrainian traditions and European influences, confessional pluralism, active cross-cultural ties. All this shaped the specificity of the Ukrainian literary landscape. In the course of "trying on names", which turned amorphous Russia into a "territory with history," the nuances of "historical memory" were recoded differently depending on the individual / group choice, however, the integration function of "memory" itself did not diminish from this, because for the first time to opponents it was said about the same thing - about "our" land and "our common" past" (Yakovenko, 2012: 43). So, as N. Yakovenko emphasizes, the "portrait" of Ukraine-borderlands in the perception of the people, who lived there differed significantly from the "self-portrait", that is, the ideas about their life space of "Ukrainian people". The most striking thing is that the cultural and geographical image of Ukraine for an outside observer was correlated not with a certain territory, but with an amorphous "outskirts of Europe". It was marked by the topos of the cultural limit, beyond which lies the malevolent Muslim East, and concrete manifestations were seen in the diversity of the population and legitimate "disorder", that is, features that, by definition, should be inherent in territories of dubious reputation" (Yakovenko, 2012: 61). 
There were two names for Rus-Ukraine at that time - Ruthenia and Roxolania. According to N. Yakovenko, the latter "was a product not so linguistic as sociocultural - a side effect of the triumphant establishment of gentry liberties in the Kingdom of Poland during the 16th century. This, in turn, prompted the emergence of a supra-ethnic and super-confessional ideology of the "gentry people". One of its strong points was the conviction that the gentry and the common people were separated by an insurmountable abyss of "other blood" (Yakovenko, 2012: 14). The basis of such a worldview was the spread of the so-called Sarmatian ideology and the Sarmatianethnogenetic legend, the essence of which was that the biblical genealogy of the gentry was derived from Noah's son Japheth, and the common people from Noah's son Ham. The Sarmatians were considered the descendants of Yafet, who settled on the lands of Russia and Poland. So, the Sarmatians were interpreted as a people, as departed from the Poles and Russians. ShlyakhtichRusyns "identified themselves with the" Sarmatian tribe of Roksolans ", brothers of the" Polish Sarmatians ", therefore, the legitimate heirs of the" Sarmatian heritage" (Yakovenko, 2012: 14).

The Renaissance thinker and writer Stanislav Orekhovsky identified his fellow countrymen from Russia with the Sarmatians-Roksolans. He called himself Ruthenus and Roxolanus. He called Russia Roksolania. As N. Yakovenko notes, "the name choice dilemma, in fact, was a dilemma of two versions of" Russianness". It is clear that both versions were completely loyal to the political fatherland - the Commonwealth, but, somewhat simplifying, the "Roksolan" version can be identified with a tolerant attitude towards everything Polish, and its circumvention - with disdain for "Poland" (Yakovenko, 2012: 18). Accordingly, on the border of two peoples and cultures - Ukrainian and Polish - two types of writers are formed, which differ precisely by their ideological principle. In general, in the XVI century. the term "roxolans" was mainly used by representatives of the Catholic movement, Rusyns-Catholics, as well as Poles who were their supporters. The name "Roksolania" is then identified with the lands that belonged to the composition of Russia, starting from the time of Vladimir the Great, that is, in fact, at the time of the baptism of the state. Consequently, the lands of the Lithuanian and Belarusian lands were seen separately and were determined by the name Lithuania or White Russia. For example, the Ukrainian-Polish writer Sebastian Klenovich in his poem "Roksolania" (1584) defines the borders of Rus, that is, Roksolania, as the lands of the Kiev region, Podillia, Galicia, Volyn. He represents the commitment to Poland and Russia at the same time, being a representative of the Catholic movement. In parallel "with the spread of the" Roksolan "version of Russian identity, a counterproposal is gaining momentum - with an expressive" anti-Latin "(and anti-Polish) overtones. Its manifesto is the emphasis on the "Greek" origins of Russia" (Yakovenko, 2012: 19).

In general, the polyformism of the Russian cultural space of the 16th century. was the main feature in the structure of the boundary identity of the Ukrainian literature of the Renaissance. It is represented by a synthesis of authentic Russian-Ukrainian traditions and European influences, confessional pluralism, active cross-cultural ties. All this shaped the specificity of the Ukrainian literary landscape. In the course of "trying on names", which turned amorphous Russia into a "territory with history," the nuances of "historical memory" were recoded differently depending on the individual / group choice, however, the integration function of "memory" itself did not diminish from this, because for the first time to opponents it was said about the same thing - about "our" land and "our common" past" (Yakovenko, 2012: 43). So, as N. Yakovenko emphasizes, the "portrait" of Ukraine-borderlands in the perception of the people who lived here differed quite significantly from the "self-portrait", that is, the ideas about their life space of "Ukrainian people". The most striking thing is that the cultural and geographical image of Ukraine for an outside observer was correlated not with a certain territory, but with an amorphous "outskirts of Europe". It was marked by the topos of the cultural limit, beyond which lies the malevolent 
Muslim East, and concrete manifestations were seen in the diversity of the population and legitimate "disorder", that is, features that, by definition, should be inherent in territories of dubious reputation" (Yakovenko, 2012: 61).

L. Shevchenko-Savchynska notes, "The bilingualism of representatives of the Ukrainian-Polish borderlands - both Ukrainian and Polish writers - is proof of bilateral interference and heterogeneity of the regional subculture. The dialogical effect of the borderline is manifested not only in the content of the works, but also in the way of expression, that is, in vocabulary, in the constituent elements of the image, in genre stylizations, etc." (Shevchenko-Savchynska,2003: 18). Most researchers are inclined to believe that at least four literary languages were used as equal in the Ukrainian cultural space of that time. In particular, book Ukrainian, Church Slavonic, Polish, and Latin.

Speaking about the Ukrainian-Polish borderland as a defining feature of the era of the Ukrainian literary Renaissance, we appeal to the concept of watercress, introduced by the Polish scientist S. Ulyash, to designate the border areas of the Polish state. The scientist substantiated the concept that the borderland is a social and cultural phenomenon, evolving, synthesizing in itself variability in time and tradition. The Polish researcher is based on the thesis of the Italian scientist U. Eco that cultural frontiers are a specific type of symbolic community, they use their own symbols, codes, respectively, changing in the minds of people, their perception of the world. According to Ulyash, watercress are carriers of certain universal values, which are manifested primarily in the literature they have created. In particular, he considers such values "polymorphism in understanding the diversity and plurality of forms, while simultaneously belonging to the same historical Slavic community" (Ulyash, 2011: 7), "cultural federalism, which means a dialogue of cultures and openness to others" (Ulyash., 2011: 7), "the meaning of individual and national identity" (Ulyash., 2011: 7), "the borderland acquires a double meaning: as an outskirts and as a territory of potential penetration, a common field of threat and hope" (Ulyash, 2011: 7), "attachment to a small homeland" (Ulyash., 2011: 7), figurative concretization of value is a house, family, neighbors (Ulyash S., 2011: 8), "the concept of art as a search for sources" (Ulyash, 2011: 7), "the cultural and creative nature of the awareness of death" (Ulyash S., 2011: 8), "the European space of Kres in the most general dimension is a model of culture and civilization" (Ulyash, 2011: 8). According to S. Ulyash, in the XVI century. Cessae "called Podillia and Ukraine" (Ulyash, 2011: 36). It was through these lands that Rzecz Pospolita "contacted the Muslim world, and local manifestations of life here acquired a common European significance, therefore the Polish" protection of cress "was a guard for the whole respublica christiana (Christian republic)" (Ulyash, 2011: 21). This was the period of the formation and separation of the idea of a multinational state into a separate idea, since many peoples were then part of the Commonwealth. It was one of the largest state formations in Europe.

So, the history of Ukrainian literature reflects the awareness of the people as its creator of their own identity, the limits of its manifestation and implementation. These boundaries correspond to the physical territory of the nation, where the cultural and literary tradition is formed, contacts with the border territories of other peoples take place. The concept of limit, borderline is interdisciplinary. Traditionally, it is believed that a border culture is formed and develops on the border of different cultural models (at least two), characterized by ambivalence, multidimensionality, multi-vector dynamism, variability, eclecticism, synthetics. Cultural and literary identity is based on identifying oneself with a specific cultural and literary tradition. The basis of the cultural and literary identification of the individual and the people is the national cultural and literary identity. Ukrainian cultural identity structurally synthesized in itself features of national character, cultural and spiritual traditions, moral and ethical norms and 
values. The identification of the essence of borderline identity as a key feature of the literature of the Ukrainian Renaissance is based on borderline, which is evidenced by the territorial location of Ukraine, its geopolitical status. The main features of the borderline of Ukrainian culture are anxiety (due to constant cultural and historical changes), mobility (the basis of the dynamic development of Ukrainian culture), diversity, heterogeneity, pluralism of the worldview. Such borderline, borderline, borderline of Ukrainian literature of the Renaissance era was decisive in the formation of Ukrainian national identity.

A modern view of identity - synthesized, presents it as a kind of mental orientation, the result of upbringing, a certain social conscious or unconscious influence. Identity is a psychological phenomenon and a form of ideology. For the literatures of the borderlands, borderlands are characterized by numerous mutual influences - spiritual, ideological, confessional, social. The problem of national identification of the authors of the borderlands, in particular the Ukrainian Renaissance times, is quite rightly determined by the majority of scholars as belonging to two or more border cultures and literatures. During the Renaissance, the concept of a nation had blurred boundaries, significantly different from the modern one. Therefore, it is necessary to take into account the Polish-Ukrainian, Ukrainian-Belarusian, Ukrainian-Russian borderlands. In general, borderline, borderline phenomena are a sign of the European Renaissance. For example, Jan Pannonius worked on the border of Hungarian and Croatian literature, the work of Erasmus of Rotterdam is associated with Dutch and Germanic humanism. In the literature of the Renaissance, achievements were synthesized that were authentic and brought by borderline. The Renaissance-humanist intelligentsia presented their own national identity as a manifestation of belonging to the Ukrainian people. Using Latin as the supranational language of education, science, culture, they marked their own national identity, taking into consideration the development of national interests and their representation in Europe. This was the time of the formation of ethno-confessional nations, represented by the national church and confessional identity.

\section{Conclusions}

To conclude, the period of the $16^{\text {th }}$ century represents the era of the Ukrainian literary Renaissance, which was formed on the verge of mainly two cultures and literatures - Ukrainian and Polish. The borderline of the Renaissance writing system determined the representation in it of the corresponding national identity - borderline with a pronounced emphasis on belonging to Rus-Ukraine, artistic comprehension of Ukrainian history. It was polymorphic literature by its nature, confessional and ethnically patriotic, syncretic in terms of manifestations of Ukrainian authentic and Western European traditions. Ukrainian literary Renaissance is an integral part of the pan-European cultural and spiritual Renaissance.

\section{References}

1. Brogi Bercoff G. (2003). Rus, Ukraina, Ruthenia, Wielkie Ksiestwo Litewskie, Preczpospolita, Moskwa, Rosja, Europa Srodkowo-Wschodnia: o wieloarstwowosci i polifuncjonalizmie kulturowym. Pisa: Ed. Aberti et al. [in Polish]

2. Efremov S. (1995). Istoriia ukrainskoi literaturu [History of Ukrainian literature]. Kyiv: Femina. [in Ukrainian]

3. Golenishchev-Kutuzov I.N. (1963). Gumanism Vostochnykh slovian [Humanism among the Eastern Slavs]. Moscow: Nauka. [in Russian] 
4. Losev A.F. (1978). Estetika Renessansa [Renaissance aesthetics]. Moscow: Mysl. [in Russian] 5. Radyshevskyi R. (2008). Ukrainsko-polske pohranychchia: sarmatyzm, baroko, dialoh kultur [Ukrainian-Polish border: Sarmatism, Baroque, dialogue of cultures]. Kyiv: Lesya. [in Ukrainian]

6. Shevchenko-Savchynska L. (2013). Latynomovna ukrainska literatura. Zahalnyi ohliad [Latin-speaking Ukrainian literature. General review]. Kyiv: Medievist. [in Ukrainian]

7. Shevchuk V. O. (2004). Muza Roksolanska. Ukrainska literatura XVI-XVIII stolit: Renesans. Rannie Baroko [Muse of Roksolanska. Ukrainian literature of the $16^{\text {th }}-18^{\text {th }}$ centuries: in 2 books.] Kyiv: Naukova dumka. [In Ukrainian]

8. Ulyash S. (2011). Literatura Pohranychchia - pohranychchia literatury [Literature Borderlands - the borderlands of literature]. Kyiv. [in Ukrainian]

9. Yakovenko N. (2012). Dzerkala identychnosti. Doslidzhennia z istorii uiavlen ta idei v Ukraini XVI- pochatku XVIII stolittia [Mirrors of identity. Research on the history of ideas in Ukraine in the 16th-early 18th centuries]. Kyiv: Laurus. [in Ukrainian] 